\title{
Obituary
}

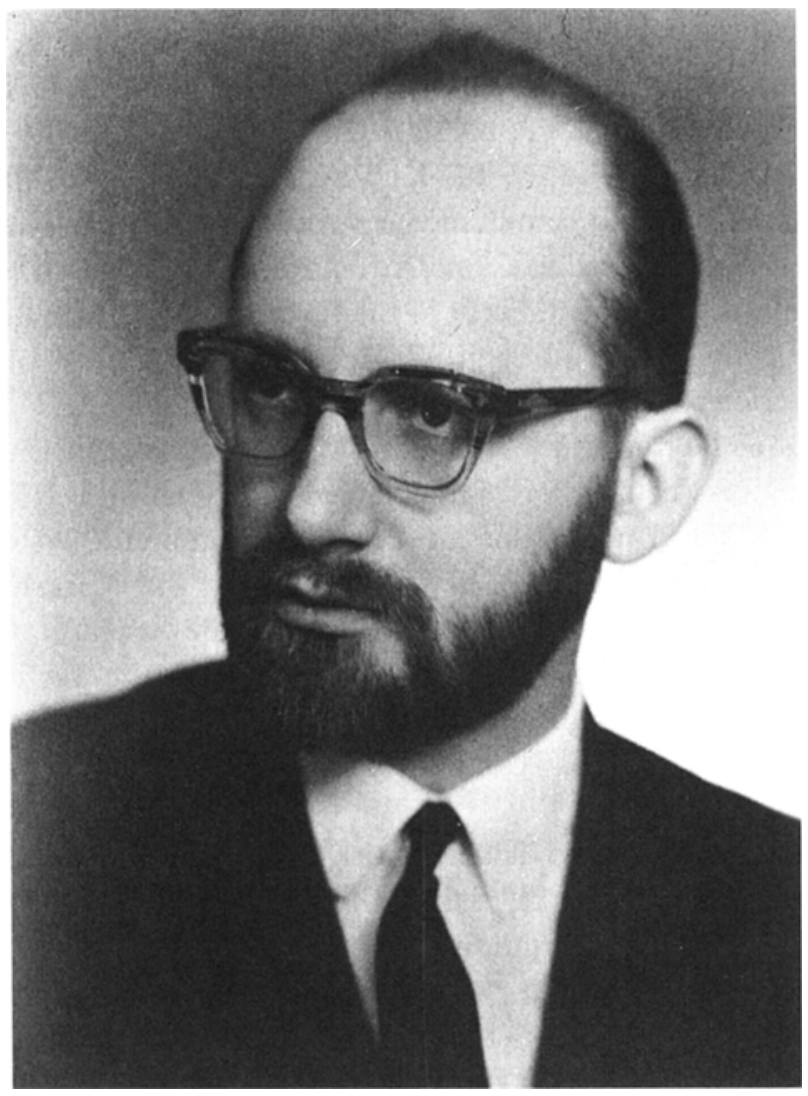

Marek Kucama, 1935-1991

\section{ROMAN GER}

Marek Kuczma was born on October 10, 1935 in Katowice (Poland). There he completed his high school and he returned there in 1963. His habilitation at the Jagello University (Krakow) in October, 1963 coincided with the establishment of the Katowice branch of the oldest Polish University. To this institution Professor 
Kuczma was attached from its very beginnings. In October, 1963 he became the head of the mathematical section of the Katowice branch of the Jagello University. Right after obtaining a position of "docent" (associate professor), he was elected vice-dean of the Faculty of Mathematics, Physics and Chemistry of the Jagello University, responsible for the Katowice branch. He held this position until mid- 68 . Independently, on December 1, 1966 he was appointed head of the Department of Functional Equations in the Katowice branch of the Jagello University.

Since the establishment of the Silesian University of Katowice in 1968 till the end of the academic year 1968/69, M. Kuczma was the head of the mathematical section of the University and, simultaneously, headed the department of functional equations. In 1969 a new organizational structure was introduced at the university and Prof. Kuczma became the director of the Institute of Mathematics. He held this position till the end of September, 1973. He was also the head of the Section of Functional Equations in this Institute until August 31, 1987.

During 1966-68 he was also working at the Mathematical Institute of the Polish Academy of Sciences (Section of Mathematical Analysis) and, from March, 1970 till September, 1975, in the Section of Complex Automatic Systems, a research center in the Katowice region where he was the head of the Workshop for Iteration Theory. Moreover, M. Kuczma was a member of the Scientific Councils of the Mathematical Institutes at the Silesian University and at the Technical University of Gliwice. He was also an official delegate of the Ministry of Science, Academic Education and Technics to the Committee of the Mathematical Sciences of the Polish Academy of Sciences.

Professor Kuczma began his didactic work already as a student in 1956 and he was conducting it without breaks until his first stroke in 1978. The stroke made long-lasting therapy and rehabilitation necessary, after which he returned to teaching. Unfortunately not for long because tragedy struck again and a second stroke restricted him to a wheel-chair and to the modest interiors of his flat at Mikolowska street in Katowice. There he could manage exclusively due to the care, angelic patience and devotion of his wife Krystyna. That is why Professor Kuczma was still able to continue his research work quite intensively. In this tragic decade (the eighties) he wrote nearly thirty mathematical papers; some of them are still in print.

Marek Kuczma died on June 13, 1991 in Katowice, after a hopeless seven months of hospitalization.

The scientific output of Professor Kuczma is enormous; it consists of 180 publications and of three mathematical monographs:

(i) Functional Equations in a Single Variable

(ii) An Introduction to the Theory of Functional Equations and Inequalities

(iii) Iterative Functional Equations. 
The first, published by Polish Scientific Publishers in 1968 in the series "Mathematical Monographs", had been the only monograph on that subject for more than twenty years and a fundamental source for the theory of functional equations in a single variable. It was quoted by all authors working in the field. The second monograph, published by the same publisher, was also a great success in the international mathematical community and is highly appreciated by the specialists. The last one, written jointly with B. Choczewski and R. Ger, was published in 1990 by Cambridge University Press in the series "Encyclopedia of Mathematics and Its Applications"; the book contains an outline of the modern theory of iterative functional equations including recent developments on the subject.

M. Kuczma's works on monotonic and convex solutions of some basic iterative functional equations immediately found interesting and elegant applications in probability theory (branching processes).

However, the paramount achievement of Professor Marek Kuczma was the creation and development of a systematic theory of iterative functional equations and founding a mathematical school centered around the seminar conducted by him since October, 1964. The author of this obituary had the honour of belonging to this school. Among Kuczma's numerous students, eleven have already their habilitations and three of them became full professors. Now students of Kuczma's students defend their habilitation theses.

The scientific achievements of Professor Kuczma and his school are widely known. He liked to travel, which led him to lecture at many European and North American universities and to accept visiting positions in Waterloo (Canada) and Marburg (Germany). He took active part at numerous international congresses, symposia and conferences. He contributed as member of the Editorial Board to "Aequationes Mathematicae" since its very beginning.

M. Kuczma was considered an outstanding mathematician highly esteemed by the international community of specialists; among the functional equationists he had commonly been treated as one of the informal leaders. His personality and influence allowed him to enjoy the respect of his entourage but also of people with loose, if any, connections to mathematics. His ingenuity, efficiency and his ability of getting fast to the crux of the matter, his uncompromising attitude and adherence to honest and respectable principles of life-all these made Kuczma a great Teacher.

A rich and fruitful career has come to an end. It remains for us to come to grips with Marek Kuczma's demise and to face the loss of a scholar whose work and personality contributed so much to the field of functional equations. The work he has done and people he inspired, remain with us. We should not bemoan that we have lost him too soon; we should be grateful that we had him among us. 


\section{MAREK KUCZMA: LIST OF PUBLICATIONS}

[1] On the functional equation $g(x+1)-g(x)=\varphi(x)$ [Polish]. Zeszyty Nauk. Univ. Jagiellon. Mat.-Fiz.-Chem. 4 (1958), 27-38.

[2] On the sums of the series $\sum_{n=1}^{\infty} n^{p} / x^{n}$ [Polish]. Zeszyty Nauk. Uniw. Jagiellon. Mat.-Fiz.-Chem. 4 (1958), 39-46.

[3] (with $\mathrm{S}$. Golab and $\mathrm{Z}$. Opial) La courbure d'une courbe plane et l'existence d'une asymptote. Ann. Polon. Math. 5(1958/59), 275-283.

[4] On the functional equation $\varphi(x)+\varphi[f(x)]=F(x)$. Ann. Polon. Math. 6 (1959), 281-287.

[5] (with J. Kordylewski) On the functional equation $F(x, \varphi(x), \varphi[f(x)])=\mathbf{0}$. Ann. Polon. Math. ? (1959), 21-32.

[6] (with S. Golab and J. Kordylewski) On some new geometrical interpretations of the torsion of a skew curve. Ann. Polon. Math. 7 (1959), 269-278.

[7] On convex solutions of the functional equation $g[\alpha(x)]-g(x)=\varphi(x)$. Publ. Math. Debrecen 6 (1959), 40-47.

[8] Bemerkung zur vorhergehenden Arbeit von M. Kucharzewski. Publ. Math. Debrecen 6 (1959), 199-203.

[9] On linear differential geometric objects of the first class with one component. Publ. Math. Debrecen 6 (1959), 72-78.

[10] Note on convex functions. Ann. Univ. Sci. Budapest. Eötvös, Sect. Math. 2 (1959), 25- 26.

[11] (with J. Kordylewski) On some functional equations [Polish]. Zeszyty Nauk. Uniw. Jagielloń. Prace Mat. 5 (1959), 23-34.

[12] (with J. Kordylewski) On the functional equation $F\left(x, \varphi(x), \varphi\left[f_{1}(x)\right], \ldots, \varphi\left[f_{n}(x)\right]\right)=0$. Ann. Polon. Math. 8 (1960), 55-60.

[13] General solution of a functional equation. Ann. Polon. Math. 8 (1960), $201-207$.

[14] On continuous solutions of a functional equation. Ann. Polon. Math. 8 (1960), 209-214.

[15] Remarks on some functional equations. Ann. Polon. Math. 8 (1960), 277-284.

[16] On the form of solutions of some functional equations. Ann. Polon. Math. 9(1960), 55-63.

[17] (with J. Kordylewski) On some linear functional equations. Ann. Polon. Math. 9 (1960), $119-136$.

[18] (with J. Aczél, S. Gołąb and E. Siwek) Das Doppelverhältnis als Lösung einer Funktionalgle ichung. Ann. Polon. Math. 9 (1960), 183-187.

[19] General solution of the functional equation $\varphi[f(x)]=G(x, \varphi(x))$. Ann. Polon. Math. 9 (1960), 275-284.

[20] On monotonic solutions of a functional equation. I. Ann. Polon. Math. 9 (1960), 295-297.

[21] Remarques sur quelques theorèmes de J. Anastassiadis. Bull. Sci. Math. (2) 84 (1960), 98-102.

[22] On some infinite series and a certain limit property of real entire functions. Acta Math. Acad. Sci. Hungar. 11 (1960), 249-253.

[23] (with M. Kucharzewski) On linear differential geometric objects with one component. I. Tensor (N.S.) $10(1960), 245-254$.

[24] (with P. Vopènka) On the functional equation $\lambda[f(x)] \lambda(x)+A(x) \lambda(x)+B(x)=0$. Ann. Univ. Sci. Budapest, Eötvös, Sect. Math. 3-4 (1960-61), 123-133.

[25] (with M. Kucharzewski) On linear differential geometric objects with one component. II. Tensor (N.S.) 11 (1961), 35-42.

[26] (with J. Kordylewski) On the continuous dependence of solutions of some functional equations on given functions. I. Ann. Polon. Math. 10 (1961), $41-48$.

[27] On monotonic solutions of a functional equation. II. Ann. Polon. Math. 10 (1961), 161-166.

[28] (with J. Kordylewski) On the continuous dependence of solutions of some functional equations on given functions. II. Ann. Polon. Math. 10 (1961), 167-174.

[29] Functional equations and their significance in modern mathematics [Polish]. Prace Mat. 6(1961), 175-211. 
[30] Sur une équation fonctionnelle. Mathematica (Cluj) 3(26) (1961), 79-87.

[31] A uniqueness theorem for a linear functional equation. Glas. Mat.-Fiz. Astr. Ser. II 16 (1961), $177-181$.

[32] On some functional equations containing iterations of the unknown function. Ann. Polon. Math. 11 (1962), 1-5.

[33] On the functional equation $\varphi^{n}(x)=g(x)$. Ann. Polon. Math. 11 (1962), 161-175.

[34] (with J. Kordylewski) On some linear functional equations. II. Ann. Polon. Math. 11 (1962), 203-207.

[35] On a recurrence relation. Colloq. Math. 9(1962), 105-108.

[36] (with M. Kucharzewski) General solution of the functional equation $f(x y)=f(x) f(y)$ for second degree matrices $f$ [Polish]. Zeszyty Nauk. Wyż. Szkoly Ped. w Katowicach Mat. 3 (1962), 47-59.

[37] (with M. Kucharzewski) Some remarks on sequences defined in a recurrent way [Polish]. Zeszyty Nauk. Wyż. Szkoły Ped. w Katowicach Mat. 3 (1962), 61-70.

[38] On some functional equations whose solutions are representable with the aid of Euler's gamma function [Polish]. Zeszyty Nauk. Wyż. Szkoły Ped. w Katowicach Mat. 3 (1962), 71-88.

[39] On the functional equation $f(x+y)=f(x)+f(y)$. Fund. Math. $50(1962), 387-391$.

[40] (with M. Kucharzewski) Sur la classification des objects géométriques linéaires homogènes de la première classe à deux composantes dans l'espace à deux dimensions. C.R. Acad. Sci. Paris 254 (1962), 1562-1563.

[41] A remark on commutable functions and continuous iterations. Proc. Amer. Math. Soc. 13 (1962), $847-850$.

[42] (with B. Choczewski) Sur certaines équations fonctionnelles considérées par I. Stamate. Mathematica (Cluj) 4 (27) (1962), 225-233.

[43] (with M. Kucharzewski) On the functional equation $F(A B)=F(A) F(B)$. Ann. Polon. Math. 13 (1963), 1-17.

[44] A characterization of the exponential and logarithmic functions by functional equations. Fund. Math. 52 (1963), 283-288.

[45] (with M. Kucharzewski) Some remarks on geometric objects and their equivalence. I. Tensor (N.S.) 13 (1963), 251-260.

[46] (with M. Kucharzewski) Some remarks on geometric objects and their equivalence. II. Tensor (N.S.) 13 (1963), 261-268.

[47] On the Schröder equation. Rozprawy Mat. 34 (1963), 50 pp.

[48] (with K. Szymiczek) On periodic solutions of a functional equation. Amer. Math. Monthly 70 (1963), 847-850.

[49] (with M. Kucharzewski) Determination of geometric objects of the type [2,2,1] with a linear homogeneous transformation formula. Ann. Polon. Math. 14 (1963), 29-48,

[50] (with M. Kucharzewski) On a system of functional equations occurring in the theory of geometric objects. Ann. Polon. Math. 14 (1963), 59-67.

[51] (with A. Zajtz) Über die multiplikative Cauchysche Funktionalgleichung für Matrizen dritter Ordnung. Arch. Math. Basel, 15 (1964), 136-143.

[52] Note on Schröder's functional equation. J. Austral. Math. Soc. 4 (1964), 149-151.

[53] A survey of the theory of functional equations. Univ. Beograd. Publ. Elektrotehn. Fak. Ser. Mat. Fiz. 130 (1964), 64 pp.

[54] Sur une équation aux différences finies et une caractérisation fonctionnelle des pôlynômes. Fund. Math. 55 (1964), 77-86.

[55] (with M. Kucharzewski) Determination of linear differential geometric objects of the first class, with two components, in a two-dimensional space. Ann. Polon. Math. 15 (1964), 77-84.

[56] (with M. Kucharzewski) Basic concepts of the theory of geometric objects. [Rozprawy Mat., No. 43]. IMPAN, Warsaw, 1964.

[57] Sur une équation fonctionnelle qui caractérise la fonction $x^{-1}$. Publ. Inst. Math. (Beograd) (N.S.) $4(18)(1964), 121-124$. 
[58] Solution d'un probleme de D. S. Mitrinović concernant une équation fonctionnelle. Univ. Beograd. Publ. Elektrotehn. Fak. Ser. Mat. Fiz. 129 (1964), 30-32.

[59] (with T. Dłotko) Sur une équation différentielle fonctionelle à l'argument accéléré. Colloq. Math. 12 (1964), 107-114.

[60] (with S. Gołąb, A. Jakubowicz and M. Kucharzewski) Sur l'objet géométrique représentant une direction munie d'un sens. Ann. Polon. Math. 16 (1964), 233-236.

[61] On a characterization of the cosine. Ann. Polon. Math. 16 (1964), 53-57.

[62] Remark on a difference equation. Prace Mat. 9 (1965), I-8.

[63] Bemerkungen über die Klassifikation der Funktionalgleichungen. Prace Mat. 9(1965), 169-183.

[64] Einige Sätze über die Reduktion der Ordnung der Funktionalgleichungen. Prace Mat. 9 (1965), $185-192$.

[65] (with S. Golab) Ober eine Eigenschaft der Systeme von Transformationen. Zeszyty Nauk. Uniw. Jagielloń. Prace Mat. 10 (1965), 21-24.

[66] On teaching inequalities in high schools [Polish]. Matematyka 18, No. 3 (87) (1965), 123-125.

[67] (with M. Kucharzewski) Klassifikation der linearen homogenen geometrischen Objekten von Typus $J$ mit drei Komponenten. [Rozprawy Mat., No. 48] IMPAN, Warsaw, 1965.

[68] On convex solutions of Abel's functional equation. Bull. Acad. Polon. Sci. Sér. Sci. Math. Astr. Phys. 13 (1965), 645-648.

[69] Third note on the general solution of a functional equation. Ann. Polon. Math. 17 (1965), $179-192$.

[70] (with B. Choczewski) On the indeterminate case in the theory of linear functional equation. Fund. Math. 58 (1966), $163-175$.

[71] On a theorem of M. Ghermănescu. Zeszyty Nauk. Uniw. Jagiellon. Prace Mat. 11 (1966), 31-39.

[72] (with A. Zajtz) On the form of real solutions of the matrix functional equation $\Phi(x) \Phi(y)=\Phi(x y)$ for non-singular matrices $\Phi$. Publ. Math. Debrecen 13 (1966), 257-262.

[73] Sur l'equation fonctionnelle de Böttcher. Mathematica (Cluj) 8(31) (1966), 279-285.

[74] (with A. Smajdor) Note on iteration of concave functions. Amer. Math. Monthly 74 (1967), $401-402$.

[75] Une remarque sur les solutions analytiques d'une équation fonctionnelle. Colloq. Math. 16 (1967), $93-99$.

[76] On a functional characterization of the logarithm. Funkcial. Ekvac. 10 (1967), 67-73.

[77] (with A. Zajtz) Quelques remarques sur l'équation fonctionnelle matricielle multiplicative de Cauchy. Colloq. Math. 18 (1967), 159-168.

[78] Un théorème d'unicité pour l'équation fonctionnelle de Böttcher. Mathematica (Cluj) 9(32) (1967), 285-293.

[79] On the convergence of iterates. Ann. Polon. Math. 20 (1968), 195-198.

[80] (with J. Burek) Einige Bemerkungen über monotone und konvexe Lösungen gewisser Funktionalgleichungen. Math. Nachr. 36 (1968), 121-134.

[81] On a conjecture of B. Schweizer. Aequationes Math. 2 (1968), 122-123.

[82] (with A. Smajdor) Fractional iteration in the class of convex functions. Bull. Acad. Polon. Sci. Sér. Sci. Math. Astr. Phys. 16 (1968), 717-720.

[83] On a new characterization of the exponential function. Ann. Polon. Math. 21 (1968), 39-46.

[84] Some remarks on a functional equation characterizing the root. Aequationes Math. 2 (1969), $282-286$.

[85] (with R. R. Coifman) On asymptotically regular solutions of a linear functional equation. Aequationes Math. 2(1969), 332-336.

[86] Analytic solutions of a linear functional equation. Ann. Polon. Math. 21 (1969), 297-303.

[87] On a functional equation with divergent solutions. Ann. Polon. Math. 22 (1969), 173-178.

[88] Fractional iteration of differentiable functions. Ann. Polon. Math. 22 (1969), 217-227.

[89] On squares of differentiable functions. Ann. Polon. Math. 22 (1969), 229-237.

[90] Problems of uniqueness in the theory of functional equations in a single variable. Zeszyty Nauk. Uniw. Jagielloń., Prace Mat. 14 (1970), 41-48. 
[91] Zur Theorie der analytischen Lösungen der Funktionalgleichungen erster Stufe. Nehézip. Müsz. Egy. Közl. ( Miskolc) 30 (1970), 251-254.

[92] Almost convex functions. Colloq. Math. 21 (1970), 279-284.

[93] P56S1 (Problem 56, Solution I). Aequationes Math. 5(1970), 326-327.

[94] (with R. Ger) On the boundedness and continuity of convex functions and additive functions. Aequationes Math. 4 (1970), 157-162.

[95] Some remarks about additive functions on cones. Aequationes Math. 4(1970), 303-306.

[96] Fractional iteration of differentiable functions with multiplier zero. Prace Mat. 14 (1970), 35-39.

[97] Some remarks on convexity and monotonicity. Rev. Roumaine Math. Pures Appl. 15 (1970), $1463-1469$.

[98] (with G. I. Targoński) On a Pre-Schröder Equation. Bull. Acad. Polon. Sci. Sér. Sci. Math. Astr. Phys. 18 (1970), $721-724$.

[99] P63R2 (Problem 63, Remark 2). Aequationes Math. 5 (1970), 327-328,

[100] (with D. Czaja-Pośpiech) Continuous solutions of some functional equations in the indeterminate case. Ann. Polon. Math. 24 (1971), 9-20.

[101] (with W. Smajdor) On the radius of convergence of series solutions of a functional equation. Ann. Polon. Math. 24 (1971), 233-240.

[102] (with A. Smajdor) Regular fractional iteration. Bull. Acad. Polon. Sci. Sér. Sci. Math. Astr. Phys. 19 (1971), 203-207.

[103] (with W. Smajdor) On the problem of uniqueness for solutions of a functional equation. Bull. Acad. Polon. Sci. Sér. Sci. Math. Astr. Phys. 19 (1971), 301-304.

[104] On integrable solutions of a functional equation. Bull. Acad. Polon. Sci. Sér. Sci. Math. Astr. Phys. $19(1971), 593-596$.

[105] Convex functions. [Corso tenuto a La Mendola (Trento) dal 20 al 28 agosto 1970]. Functional Equations and Inequalities. Cremonese, Roma, 1971, pp. 195-213.

[106] (with J. Drewniak) On the asymptotic behaviour of some sequences built of iterates. Ann. Polon. Math. 25 (1971), 39-51.

[107] (with L. Dubikajtis) On non-localized oriented angles. Ann. Polon. Math. 25 (1971), 235-247.

[108] (with Marcin E. Kuczma) An elementary proof and extension of a theorem of Steinhaus. Glas. Mat. Ser. III 6(26) (1971), 11-18.

[109] On a problem of the optimalization of a discrete process with bounds at every step. Podstawy sterowania 1 (1971), 153-160.

[110] On a problem of the optimalization of a discrete process with bounds at every step. Bull. Acad. Polon. Sci. Sér. Sci. Techn. 20 (1972), no. 2, 15-17.

[111] On a problem of the optimalization of a discrete process with bounds at every step [Polish]. Prace Zakt. Syst. Automat. Kompleks. PAN 6 (1972), 3-26.

[112] On the stability of a discrete process with bounds at every step. Podstawy sterowania 2 (1972), 97-104.

[113] (with W. Smajdor) Analytic solutions of some functional equations. J. London Math. Soc. (2) 4 (1972), 418-424.

[114] Note on additive functions of several variables. Uniw. Sląski w Katowicach Prace Nauk.-Prace Mat. 2 (1972), 49-51.

[115] On a certain series. Ann. Polon. Math. 26 (1972), 199-204.

[116] (with J. Matkowski) Solutions of a functional equation in a special class of functions. Ann. Polon. Math. 26 (1972), 287-293.

[117] (with B. Choczewski) On a problem of Lipinski concerning an integral equation. Colloq. Math. 25 (1972), 113-115.

[118] Special solutions of a functional equation. Ann. Polon. Math. 27 (1972), $29-32$.

[119] A remark concerning measure and category. Uniw. Slaski w Katowicach Prace Nauk.-Prace Mat. 3 (1973), $51-52$.

[120] On some set classes occurring in the theory of convex functions. Comment. Math. Prace Mat. 17 (1973), 127-135. 
[121] (with R. Ger) On the structure of continuous solutions of some functional equations. Uniw. Ślaski w Katowicach Prace Nauk.-Prace Mat. 4(1973), 13-21.

[122] (with L. Dubikajtis, C. Ferens and R. Ger) On Mikusinski's functional equation. Ann. Polon. Math. 28 (1973), 39-47.

[123] Quelques observations à propos de l'équation Pré-Schröder. Ann. Polon. Math. 28 (1973), 49-52.

[124] Remarks concerning the general solution of a functional equation. Bul. Stiint. Tehn. Inst. Politehn. "Traian Vuia" Timişoara 16(30) (1971), 154-165.

[125] Functional equations in the theory of branching processes [Polish]. Wiadom. Mat. I6 (1973), $13-22$.

[126] Cauchy's functional equation on a restricted domain. Colloq. Math. 28 (1973), 313-315.

[127] Activity of Professor Stanistaw Golab in the theory of functional equations. Demonstratio Math. 6 (1973), 39-44.

[128] A contribution to the theory of fractional iteration of differentiable functions. Demonstratio Math. $6(1973), 181-189$.

[129] Note on a linearization. Ann. Polon. Math. 29 (1974), 75-81.

[130] (with Pl. Kannappan) On a functional equation related to the Cauchy equation. Ann. Polon. Math. 30 (1974), 49-55.

[131] Uniqueness of solutions of functional equations in a single variable [Russian]. Proceedings of the Symposium on Diflerential Equations with Deviated Argument [Kiev, September 1975]. Naukowa Dumka, Kiev, 1977, pp. 187-199.

[132] Normalizing factors for iterates of random valued functions. Uniw. Sląski w Katowicach Prace Nauk.-Prace Mat. 6 (1975), 67-72.

[133] On a theorem of Roman Ger. Uniw. Slaski w Katowicach Prace Nauk-Prace Mat. 6 (1975), $73-76$.

[134] (with R. Ger) On inverse additive functions. Boll. Un. Mat. Ital. II (1975), 490-495.

[135] Various aspects of the functional equation of Schröder. Colloques Internationaux du C.N.R.S. No. 229. Transformations ponctuelles et leurs applications [Toulouse, 10-14, September 1973], C.N.R.S., Paris, 1976, pp, 245-257.

[136] Regularly varying solutions of a linear functional equation. J. Austral. Math. Soc. 22 (1976), $135-143$.

[137] (with J. Smital) On measures connected with the Cauchy equation. Aequationes Math. I4 (1976), $421-428$.

[138] (with J. W. Brown) Self-inverse Sheffer sequences. SIAM J. Math. Anal. 7 (1976), 723-728.

[139] On mappings preserving linear independence and dependence. Uniw. Slaski w Katowicach Prace Nauk.-Prace Mat. 7 (1977), $29-49$.

[140] On the number of continuous solutions of a functional equation. Uniw. Śaski w Katowicach Prace Nauk.-Prace Mat. 7 (1977), 51-55.

[141] General continuous solution of a linear homogeneous equation. Ann. Polon. Math. 35 (1977), $21-25$.

[142] (with K. Baron) Iteration of random valued functions on the unit interval. Colloq. Math. 37(1977), $263-269$.

[143] Additive functions and the Egorov theorem. General Inequalities 1 (Proceedings of the Symposium, Oberwolfach, 1976), E. F. Beckenbach (ed.). [ISNM 41]. Birkhäuser Verlag, Basel and Stuttgart, 1978, pp. $191-197$.

[144] On some alternative functional equations. Aequationes Math. 17(1978), 182 198.

[145] Functional equations on restricted domains. Aequationes Math. 18 (1978), 1-34.

[146] Non-negative continuous solutions of a functional inequality. Ann. Polon. Math. 36 (1979), $187-199$.

[146a] Nonnegative continuous solutions of a linear functional inequality. General Inequalities 1 (Proceedings of the Symposium, Oberwolfach, 1976), E. F. Beckenbach (ed.). [ISNM 41]. Birkhäuser Verlag, Basel and Stuttgart, 1978, pp. 175-180. 
[147] (with E. Glowacki) Some remarks on Hosszú's functional equation on integers. Uniw. Sląski w Katowicach Prace Nauk.-Prace Mat. 9 (1979), 53-63.

[148] (with J. Kalinowski) Some remarks on continuous solutions of a functional equation. Uniw. Slaski w Katowicach Prace Nauk.-Prace Mat. 9 (1979), 64-73.

[149] Regular fractional iteration of convex functions. Ann. Polon. Math. 38 (1980), 95-100.

[150] On a theorem of B. Barna. Aequationes Math. 21 (1980), 173-178.

[151] (with R. Graw) Infinite discrete sets of limit points of iterative sequences of continuous functions. Aequationes Math. 22 (1981), 64-69.

[152] (with B. Choczewski) Asymptotic properties of discontinuous solutions of a functional equation. Zeszyty Nauk. Uniw. Jagiellon., Prace Mat. 22 (1981), 119-123.

[153] Functional equations. [S. Kotz-N. L. Johnson: Encyclopedia of Statistical Sciences, vol. 3]. Wiley, New York, 1983, pp. 259-261.

[154] (with B. Choczewski) Discontinuous solution of an inhomogeneous linear functional equation. Zeszyty Nauk. Uniw. Jagielloń., Prace Mat. 24 (1984), 155-158.

[155] On some properties of Erdös sets. Colloq. Math. 48 (1984), 127-134.

[156] On some analogies between measure and category and their applications in the theory of additive functions. Ann. Math. Sil. 1(13) (1985), 155-162.

[157] (with B. Choczewski) On a system of functional equations. Aequationes Math. 28 (1985), $262-268$.

[158] On a result of Z. Kominek. Rad. Mat. 3 (1987), 307--315.

[159] On some properties of solutions of a functional equation. Opuscula Math. 3 (1987), 37-41.

[160] A generic property of a linear functional equation. Opuscula Math. 4(1988), 139-144.

[161] An example of semilinear topologies. Stochastica 12 (1988), 197-205.

[162] (with Z. Kominek) Theorems of Bernstein-Doetsch, Piccard and Mehdi and semilinear topology, Arch. Math. (Basel) 52 (1989), 595-602.

[163] (with B. Choczewski) A remark on doubly stochastic measures and functional equations. C.R. Math. Rep. Acad. Sci. Canada 11 (1989), 127-132.

[164] Note on microperiodic functions. Rad. Mat. 5 (1989), 127-140.

[165] (with Z. Kominek) On the lower hull of convex functions. Aequationes Math. 38 (1989), 192-210.

[166] (with J. Aczèl) On two mean value properties and functional equations associated with them. Aequationes Math. 38 (1989), 216-235.

[166a] (with J. Aczel) On two related types of functional equations describing mean value properties. Zeszyty Nauk. Politech. Śląsk. Mat.-Fiz. 64 (1991). 37-35.

[167] Note on multipllicative functions. Ann. Math. Sil. 3 (15) (1990), 45-50.

[168] On the quasiarithmetic mean in a mean value property and the associated functional equation. Aequationes Math. 41 (1991), 33-54.

[169] (with H. Swiatak) Newton-like algorithms for $k$ th root calculation. Ann. Polon. Math. 52 (1991), $303-312$.

[170] (with J. Aczél) Generalizations of a "folk theorem" on simple functional equations in a single variable. Resultate Math. 19 (1991), 5-21.

[170a] (with J. Aczél) Solutions of a functional equation, convex of higher order. General Inequalities 6 (Proceedings of the Symposium, Oberwolfach, 1990), edited by W. Walter (to appear).

[171] (with Z. Kominek) p-convex functions in linear spaces. Ann. Polon. Math. 53 (1991), 91-108.

[172] On a Stamate-type functional equation. Publ. Math. Debrecen 39 (1991), 325-338.

[173] A note on the core topology. Ann. Math. Sil. 5(17) (1991), 28-36.

[174] (with Z. Kominek) Theorem of Bernstein-Doetsch in Baire spaces. Ann. Math. Sil. 5(17) (1991), $10-17$.

[175] (with V. Faber and J. Mycielski) Some modeis of plane geometries and a functional equation. Colloquium Math. (to appear).

[176] On some functional equations with conic sections as solutions. Rocznik Nauk.-Dydakt. WSP Krak. w. Prace Mat. (to appear). 
[177] On measurable functions with vanishing differences (submitted).

[178] On a functional equation occurring in astrophysics (submitted).

[179] (with B. Choczewski) On iterative roots of polynomials (submitted).

\section{BOOKS}

I. Functional equations in a single variable. Monografie Mat. 46. Polish Scientific Publishers, Warszawa, 1968.

II. (editor) Functional equations in the theory of stochastic processes [Polish]. Silesian University, Katowice, 1972.

III. An introduction to the theory of functional equations and inequalities. Cauchy's equation and Jensen's inequality. [Prace Nauk. Uniw. Slạski, Vol. 489]. Polish Scientific Publishers, Warszawa-KrakówKatowice, 1985.

IV. (with B. Choczewski and R. Ger) Iterative functional equations. [Encyclopedia of Mathematics and Its Applications]. Cambridge University Press, Cambridge-New York-Port Chester-MelbourneSydney, 1990. 